\title{
Kajian Quasi Linear Convective System Di Bengkulu Pada Tanggal 10 November 2017 Menggunakan WRF-ARW
}

\author{
Amalia Khoirunnisa ${ }^{1 *}$, Rizky Umul Nisa Fadillah², Marselinus Muaya ${ }^{3}$, Fitria Puspita \\ $\mathrm{Sari}^{4}$ \\ ${ }^{1,2,3}$ Program Studi Meteorologi, Sekolah Tinggi Meteorologi Klimatologi dan Geofisika, Jalan \\ Perhubungan I No.5 Pondok Betung, Bintaro, Kec. Pd. Aren, Kota Tangerang Selatan, Banten 15221 \\ ${ }^{4}$ Dosen Program Studi Meteorologi, Sekolah Tinggi Meteorologi Klimatologi dan Geofisika, Jalan \\ Perhubungan I No.5 Pondok Betung, Bintaro, Kec. Pd. Aren, Kota Tangerang Selatan, Banten 15221

\section{E-mail: *amaliakhnnisa09@gmail.com}

\begin{abstract}
The Quasi Linear Convective System (QLCS) is a meso-scale convective weather system that has the potential to bring heavy rains and destructive strong winds. One of the Quasi Linear Convective Systems (QLCS) that have occurred in Indonesia is the QLCS that was formed in Bengkulu on November 10, 2017. QLCS can be identified using weather radar observations through maximum reflectivity imagery that forms long lines. WRF-ARW (Weather Research and Forecasting - Advanced Research) weather modeling is able to simulate meso-scale atmospheric conditions. This study aims to examine the phenomenon of QLCS using identification of weather radar observations and the results of WRF-ARW modeling. The results showed a QLCS with a length of $82 \mathrm{~km}$, began to form at 09:30 UTC and reached its peak at 10.50 UTC with a maximum reflectivity of $63 \mathrm{dBz}$. Atmospheric dynamics conditions in the form of wind / streamline patterns, vertical velocity, relative humidity, Convective Available Potential Energy (CAPE) and cloud fraction from WRF-ARW model outputs show a suitable pattern and support the occurrence of convective systems around the scene. Wind patterns at the time of the event indicate a convergence region. Meanwhile the vertical velocity value reaches a peak of $0.8 \mathrm{~Pa} / \mathrm{s}$ before QLCS starts entering the mature phase. The relative humidity is $95 \%-100 \%$ and the CAPE value reaches $1000 \mathrm{~J} / \mathrm{Kg}$ to $1500 \mathrm{~J} / \mathrm{Kg}$. Cloud fraction in the layer near the surface reaches $1 \%$. Verification results with observational data show that rainfall parameters produce smaller errors compared to the results of verification reflectivity values. This shows that the WRF-ARW model is still inaccurate in modeling reflectivity data.
\end{abstract}

Keywords: QLCS, WRF-ARW, Atmospheric Dynamics, Weather Radar, Bengkulu

\begin{abstract}
Abstrak: Quasi Linear Convective System (QLCS) merupakan sistem cuaca konvektif skala meso yang berpotensi membawa hujan lebat dan angin kencang yang sifatnya merusak. Salah satu Quasi Linear Convective System (QLCS) yang pernah terjadi di Indonesia adalah QLCS yang terbentuk di Bengkulu pada tanggal 10 November 2017. QLCS dapat diidentifikasi menggunakan pengamatan radar cuaca melalui citra reflectivity maksimum yang membentuk garis memanjang. Pemodelan cuaca WRF-ARW (Weather Research and Forecasting - Advanced Research) mampu mensimulasikan kondisi atmosfer skala meso. Penelitian ini bertujuan untuk mengkaji fenomena QLCS dengan menggunakan identifikasi pengamatan radar cuaca dan hasil permodelan WRF-ARW. Hasil penelitian menunjukkan QLCS dengan panjang 82 $\mathrm{km}$, mulai terbentuk pada pukul 09.30 UTC dan mencapai puncaknya pada pukul 10.50 UTC dengan reflectivity maksimum $63 \mathrm{dBz}$. Kondisi dinamika atmosfer yang berupa pola angin/streamline, vertical velocity, kelembapan relatif, Convective Available Potential Energy (CAPE) dan cloud fraction hasil keluaran model WRF-ARW menunjukan pola yang sesuai dan mendukung terjadinya sistem konvektif di sekitar lokasi kejadian. Pola angin pada waktu kejadian menunjukan adanya daerah konvergensi. Sementara itu nilai vertical velocity mencapai puncaknya $0.8 \mathrm{~Pa} / \mathrm{s}$ pada saat sebelum QLCS mulai memasuki fase matang. Kelembaban relatif sebesar $95 \%-100 \%$ dan nilai CAPE mencapai $1000 \mathrm{~J} / \mathrm{Kg}$ hingga $1500 \mathrm{~J} / \mathrm{Kg}$. Cloud fraction di lapisan dekat permukaan mencapai $1 \%$. Hasil verifikasi dengan data observasi menunjukan parameter curah hujan menghasilkan error yang lebih kecil dibandingkan dengan error hasil verifikasi nilai reflectivity. Hal tersebut menunjukan bahwa model WRF-ARW masih kurang akurat dalam memodelkan data reflectivity.
\end{abstract}


Kata kunci: QLCS, WRF-ARW, Dinamika Atmosfer, Radar Cuaca, Bengkulu

\section{PENDAhULUAN}

Wilayah tropis merupakan tempat yang masif untuk terjadinya pertumbuhan awan konvektif karena penerimaan panas matahari sepanjang tahun. Indonesia merupakan daerah yang berada di wilayah tropis yang memiliki keunikan dan kompleksitas pembentukan awan, cuaca dan iklim (Tjasyono dan Harijono, 2013) salah satunya Quasi Linear Convective System (QLCS). Quasi Linear Convective System (QLCS) adalah salah satu bagian dari sistem cuaca konvektif Mesoscale Convective System (MCS) yang termasuk kategori skala Meso- $\beta$ dengan panjang skalanya 25 sampai $250 \mathrm{~km}$ (Orlanski, 1975).

Menurut penelitian Lombardo dan Colle (2010) karakteristik QLCS memiliki panjang $\geq$ $50 \mathrm{~km}$ dengan rasio panjang dan lebar maksimal 5:1. Reflectivity yang teramati oleh radar memiliki nilai $\geq 35 \mathrm{dBz}$ sepanjang sistem awan konvektif tersebut. Sistem awan dalam QLCS tidak memiliki batas hidup dan dapat berkembang di darat (Astuti dkk, 2019)

Komplektivitas pembentukan awan pada wilayah tropis perlu dikaji karena awan merupakan sumber fenomena cuaca lainnya. Data observasi yang tersebar dan kontinuitas data belum mampu memenuhi kebutuhan analisis sehingga perlu adanya sumber data pendukung. Pemodelan cuaca WRF-ARW (Weather Research and Forecasting - Advanced Research) adalah model cuaca yang dibuat untuk mensimulasikan kondisi atmosfer dalam skala meso sehingga mampu menganalisis dan memprediksi kondisi atmosfer yang terjadi. Namun, dalam pemodelan cuaca WRF-ARW perlu dilakukan parameterisasi karena tidak sepenuhnya mengakomodir persamaan atmosfer secara eksplisit. Hal ini disebabkan proses yang terjadi di atmosfer yang tidak dapat dipresentasikan langsung oleh model karena resolusinya lebih rendah dari resolusi model (Skamarock et al, 2008).

Penelitian ini mengkaji keadaan dinamika atmosfer saat kejadian Quasi Linear Convective System (QLCS) di wilayah Bengkulu pada tanggal 10 November 2017 berdasarkan analisis model WRF-ARW. Selain itu, dilakukan verifikasi untuk menguji keakuratan dan mengetahui kemampuan model WRF-ARW dalam simulasi kondisi atmosfer saat kejadian. Verifikasi dilakukan dengan menggunakan data banding radar cuaca serta data observasi.

\section{METODE DAN METODE}

Lokasi penelitian ini adalah wilayah Bengkulu dengan koordinat $5^{\circ} 40^{\prime}-2^{\circ} 0^{\prime}$ LS dan $100^{\circ} 40^{\prime}-$ $104^{\circ} 0^{\prime}$ BT. Data yang digunakan adalah data masukan Final Analysis (FNL) dengan resolusi spasial $10 \times 10(111 \mathrm{~km})$ dan resolusi temporal dengan interval 6 jam pada tanggal 8 November 2017 jam 00 UTC sampai tanggal 10 November 2017 jam 18 UTC yang diperoleh dari website http://rda.ucar.edu. Data tanggal 8 dan 9 November 2017 digunakan sebagai spin-up time dan tanggal 10 November 2017 merupakan data yang akan dianalis. Data banding yang digunakan citra radar reflectivity pada tanggal 10 November 2017 dari Stasiun Meteorologi Fatmawati Soekarno Bengkulu, dan data intensitas curah hujan dari beberapa titik Automatic Rain Gauge (ARG) tanggal 10 November 2017 yang terdapat dalam area cakupan radar Bengkulu. Data FNL yang digunakan untuk analisis memiliki konfigurasi seperti ditunjukkan pada Tabel 1. 
Tabel 1. Tabel Konfigurasi WRF

\begin{tabular}{cccc}
\hline \multirow{2}{*}{ Konfigurasi } & \multicolumn{3}{c}{ Domain Model WRF-ARW } \\
\cline { 2 - 4 } & Domain 1 & Domain 2 & Domain 3 \\
\hline Resolusi & $27 \mathrm{~km}$ & $9 \mathrm{~km}$ & $3 \mathrm{~km}$ \\
Mikrofisis & Lin et al. & Lin et al. & Lin et al. \\
Short Wave Radiation & Dudhia & Dudhia & Dudhia \\
Long Wave Radiation & RRTM & RRTM & RRTM \\
Land Surface & Noah LSM & Noah LSM & Noah LSM \\
Planetary Boundary Layer & YSU & YSU & YSU \\
& Scheme & Scheme & Scheme \\
Cumulus Parameterization & Kain- & Kain- & Kain- \\
& Fritsch & Fritsch & Fritsch \\
\hline
\end{tabular}

Metode yang digunakan dalam penelitian ini adalah metode deskriptif, yaitu meneliti, mengolah data, menganalisis dan menginterpretasikan dinamika atmosfer QLCS yang terjadi di Bengkulu pada tanggal 10 November 2017 dengan model WRF-ARW (Weather Research and Forecasting - Advanced Research). Langkah - langkah yang dilakukan dalam penelitian ini terkait QLCS yaitu menganalisis data keluaran radar cuaca untuk mengetahui siklus hidup QLCS yang terjadi di Bengkulu pada tanggal 10 November 2017. Setelah itu dilakukan analisis terhadap keadaan dinamika atmosfer saat kejadian QLCS dengan menggunakan parameter streamline, vertical velocity, kelembapan relatif, CAPE, dan cloud fraction hasil keluaran model WRF-ARW. Kemudian dilakukan verifikasi parameter curah hujan dan reflectivity menggunakan metode statistik yaitu korelasi, Root Mean Square Error (RMSE) dan Mean Absolute Error (MAE).

\section{HASIL DAN PEMBAHASAN}

\subsection{Analisis Karakteristik Nilai Parameter Waldvogel Modifikasi}

Radar cuaca sebagai instrumen dalam mengidentifikasi QLCS karena radar dapat menggambarkan secara detail dan cepat tentang kondisi lingkungan sekitar secara realtime (Wardoyo, 2015). Kejadian QLCS yang terjadi di bengkulu teramati oleh radar cuaca (Gambar 1). Hasil pengolahan Produk MAX menujukkan karakteristik kontur reflectivity teramati memenuhi syarat kriteria menurut Lombardo dan Colle (2010). Panjang QLCS teramati $82 \mathrm{~km}$, reflectivity minimum $38 \mathrm{dBZ}$, reflectivity maksimum $63 \mathrm{dBZ}$. Identifikasi fase kejadian QLCS menunjukan fase inisiasi teramati pada 09.30 UTC hingga 10.00 UTC yang ditandai dengan nilai reflectivity mulai lebih dari $35 \mathrm{dBZ}$, fase matang teramati pada 10.10 UTC hingga 10.50 UTC ditandai dengan nilai reflectivity mencapai nilai maksimum dalam rentang $58 \mathrm{dbz}$ hingga $63 \mathrm{dBZ}$, dan menurunnya nilai reflectivity mulai pada jam 11.00 UTC menunjukan indikasi QLCS memasuki fase disipasi 


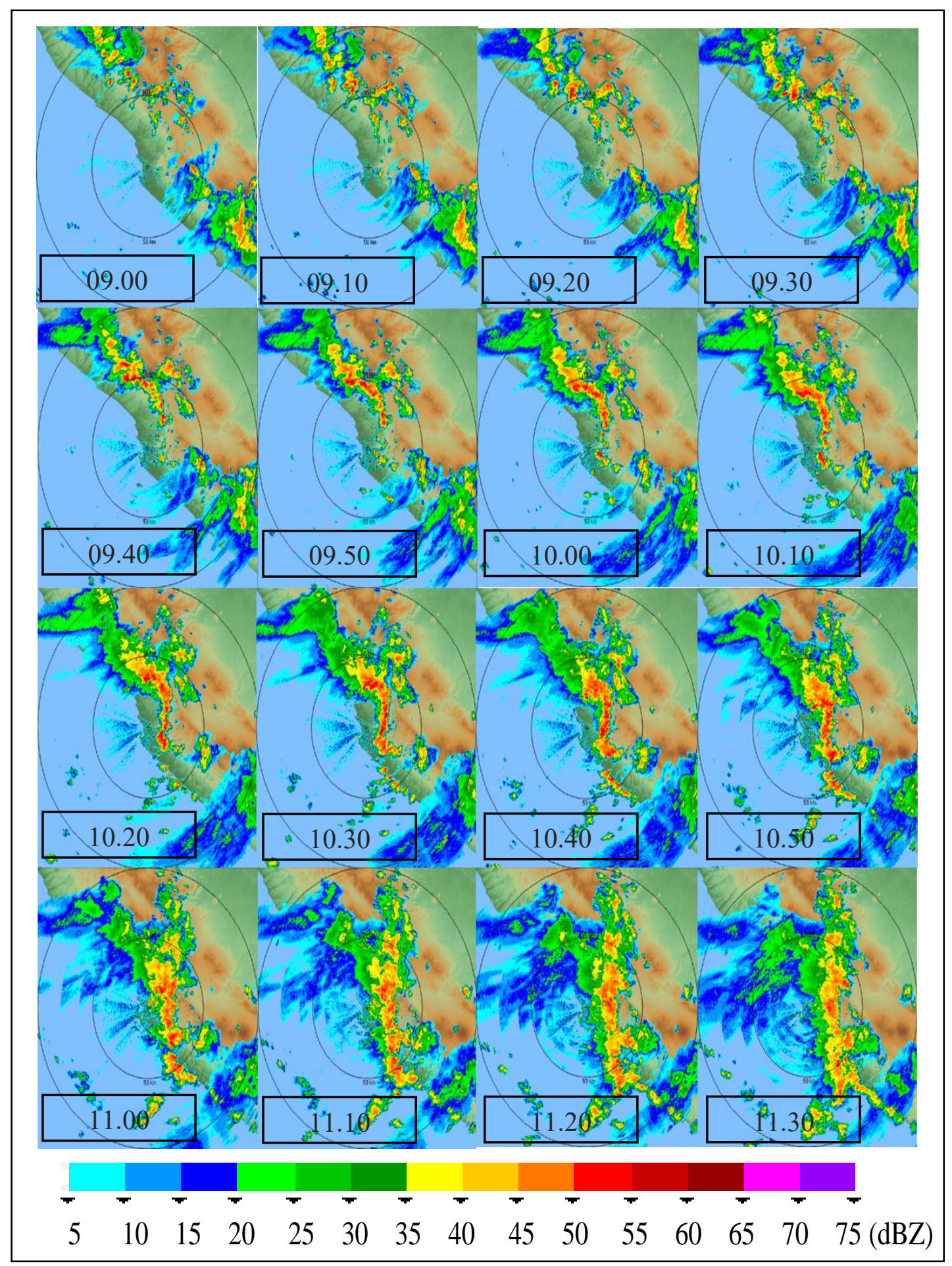

Gambar 1. Citra Radar Bengkulu Produk MAX jam 09.00 UTC-11.30 UTC 10 November 2017 yang menunjukan kontur reflectivity QLCS

\subsection{Analisa Parameter dan Kondisi Atmosfer Hasil Prakiraan Model WRF-ARW}

Analisis dilakukan terhadap parameter-parameter luaran model WRF-ARW pada saat kejadian QLCS di Bengkulu 10 November 2017. Parameter-parameter yang dianalisis merupakan parameter yang dapat mengindikasikan terjadinya QLCS diantaranya adalah pola 
angin/streamline, vertical velocity, kelembapan udara relatif, Convective Available Potential Energy (CAPE), dan cloud fraction.

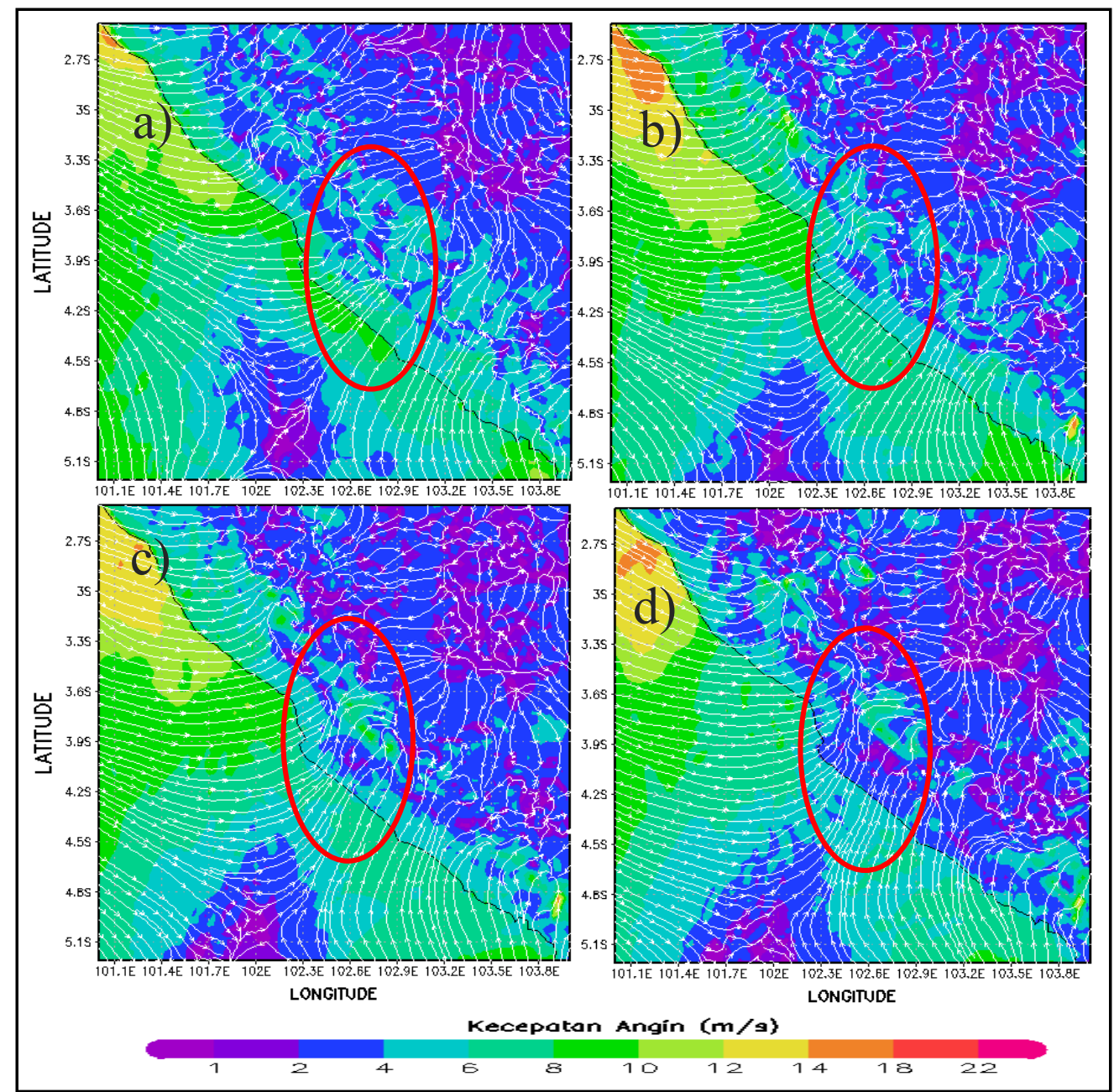

Gambar 2. Streamline lapisan $900 \mathrm{mb}$ pada tanggal 10 November 2017 (a) pukul 03 UTC (b) pukul 06 UTC (c) pukul 09 UTC (d) pukul 12 UTC

Pola angin/streamline berdasarkan hasil luaran WRF-ARW tanggal 10 November 2017 pukul 00.00 UTC, 03.00 UTC, 09.00 UTC dan 12.00 UTC (Gambar 2) menunjukkan adanya konvergensi pada sekitar lokasi terjadinya QLCS (lingkar merah). Pola konvergensi yang teramati merupakan pertemuan angin dari arah barat-barat laut dan dari arah tenggara yang kemudian berkumpul dan mengarah timur laut yang juga menuju ke daratan. Pola ini mulai terbentuk sekitar pukul 06.00 UTC dan semakin terlihat jelas seiring pertambahan waktu. Proses tersebut juga ditandai dengan kecepatan angin yang melambat di sekitar area konvergen. Hal tersebut menjadi pemicu pergerakan udara ke atas yang sangat mendukung pembentukan awan. 


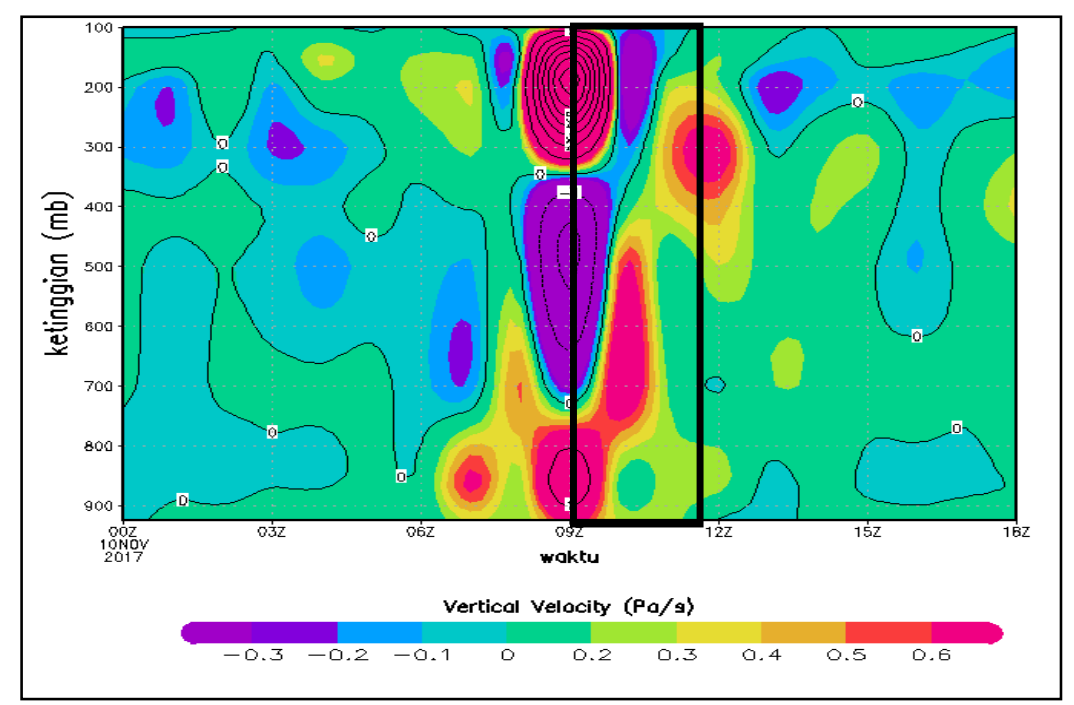

Gambar 3. Vertical velocity dalam profil vertikal pada jam 00-18 UTC 10 November 2017 di Bengkulu.

Gambar 3 menunjukkan nilai vertical velocity selama pertumbuhan, pengembangan, dan peluruhan QLCS. Jika kecepatan vertikal $(\mathrm{Pa} / \mathrm{s})$ positif, ini menunjukkan ada pergerakan massa udara naik secara vertikal untuk membentuk awan. Sebaliknya, jika kecepatan vertikal negatif menunjukkan ada gerakan massa udara yang menurun. Nilai yang meningkat menunjukkan kecepatan pergerakan massa udara. Dalam Gambar tersebut, terlihat bahwa pada jam 09 UTC hasil WRF menunjukkan dengan jelas vertical velocity bernilai positif pada lapisan dekat permukaan yang menunjukkan adanya massa udara yang bergerak ke atas. Vertical velocity pada lapisan dekat permukaan mulai mengalami peningkatan mulai dari pukul 06 UTC dan mencapai puncaknya pada pukul 9 UTC hingga 10 UTC dengan nilai mencapai $0.7 \mathrm{~Pa} / \mathrm{s}$.

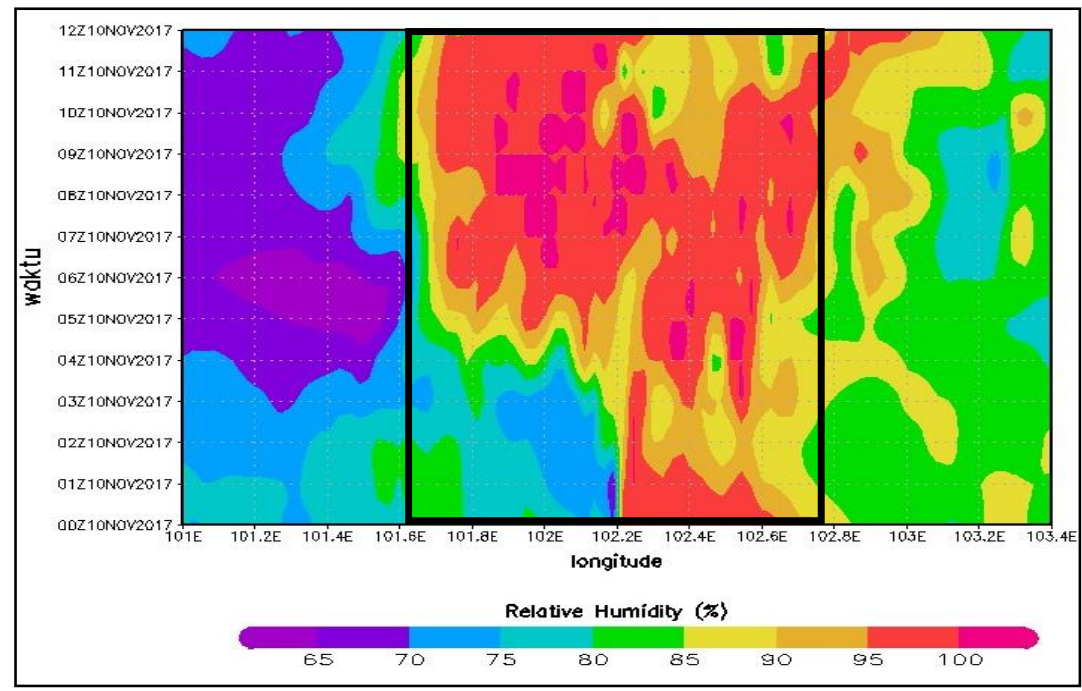

Gambar 4. Kelembapan udara relatif lapisan $850 \mathrm{mb}$ pada jam 00-12 UTC 10 November 2017 di Bengkulu 
Gambar 4 adalah hasil kelembapan udara dari WRF-ARW yang berpusat pada koordinat lokasi Stasiun Meteorologi Fatmawati Soekarno Bengkulu bahwa kelembapan udara sangat basah antara 85 - 100\% terjadi dari jam 05-12 UTC di sekitar wilayah terjadinya Quasi Linear Convective System (QLCS). Namun, terdapat juga kelembapan udara dengan nilai antara 65 $80 \%$ pada wilayah lain. Kelmebapan udara yang tinggi ini mendukung pembentukan Quasi Linear Convective System (QLCS).

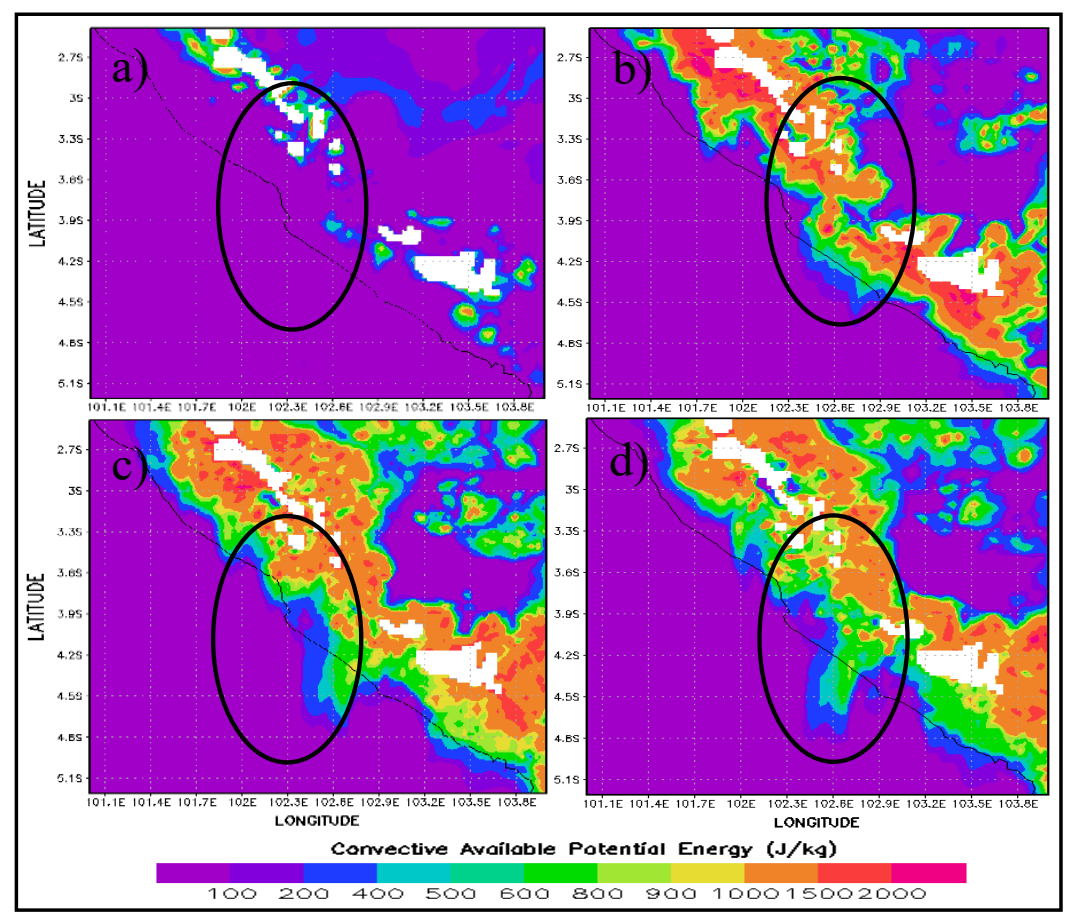

Gambar 5. CAPE lapisan 850mb 10 November 2017 di Bengkulu (a) pukul 03 UTC (b) pukul 06 UTC (c) pukul 09 UTC (d) pukul 12 UTC

Nilai CAPE di sekitar wilayah Bengkulu pada kejadian Quasi Linear Convective System (QLCS) tanggal 10 November 2017 (Gambar 5) menunjukkan pada pukul 06 UTC nilai CAPE meningkat secara signifikan mencapai $>1500 \mathrm{~J} / \mathrm{kg}$ dibandingkan pukul 03 UTC. Nilai CAPE $>1500 \mathrm{~J} / \mathrm{kg}$ semakin meluas pada pukul 09 UTC yang mengindikasikan adanya energi pengangkatan parsel ke lapisan atas serta berpotensi tumbuhnya awan-awan konvektif yang berukuran besar. Terlihat pola batas memanjang yang jelas antara nilai CAPE kecil $<200 \mathrm{~J} / \mathrm{kg}$ disebelah barat dari nilai CAPE besar $>2500 \mathrm{~J} / \mathrm{kg}$ menunjukkan adanya perbedaan gaya apung yang besar. 


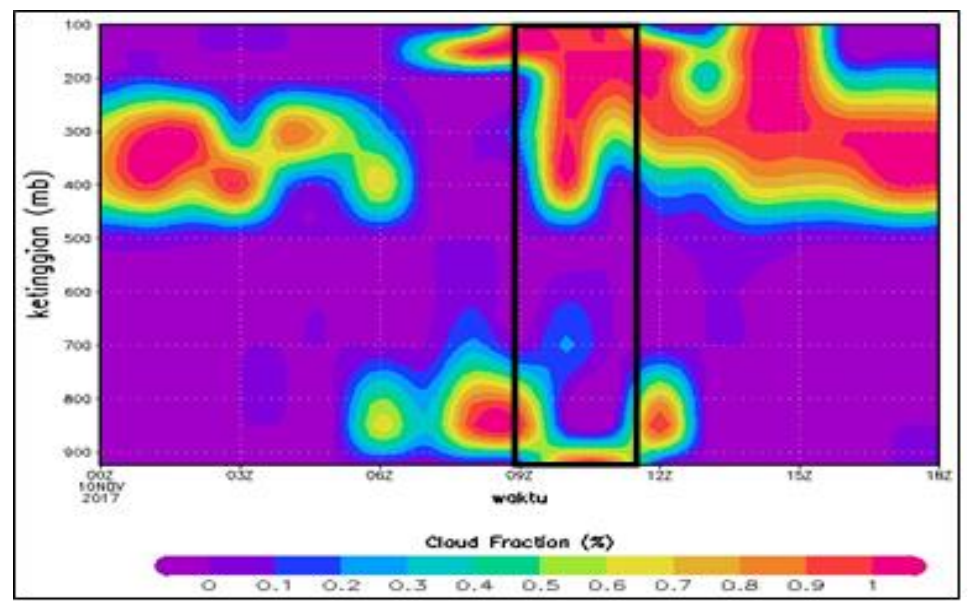

Gambar 6. Cloud fraction dalam profil vertikal pada pukul 00-23 UTC

10 November 2017 di Bengkulu

Gambar 6 adalah hasil Cloud Fraction (\%) dari WRF-ARW yang berpusat pada koordinat lokasi Stasiun Meteorologi Fatmawati Soekarno Bengkulu. Dalam Cloud Fraction ditampilkan profil vertikal di mana jika kita melihat pada jam 09 sampai 11 UTC jelas menunjukkan pola yang mendukung pembentukan Quasi Linear Convective System (QLCS) dengan nilai persentase Cloud Fraction mencapai 1\% yang menunjukkan bahwa pada lapisan tersebut tertutup awan yang sangat tebal.

\subsection{Verifikasi}

\subsubsection{Intensitas Curah Hujan Hasil Model WRF-ARW dengan AWS/ARG}

Hubungan intensitas curah hujan hujan ARG dengan hasil keluaran model WRF-ARW pada kejadian QLCS pada tanggal 10 November 2017 di Bengkulu (Gambar 7). Dari masing-masing grafik tersebut diperoleh nilai korelasi intensitas curah hujan Automatic Rain Gauge (ARG) dengan hasil keluaran WRF-ARW beserta nilai error rata-rata kuadrat (RMSE) dan nilai error rata-rata absolut (MAE) pada Tabel 2.

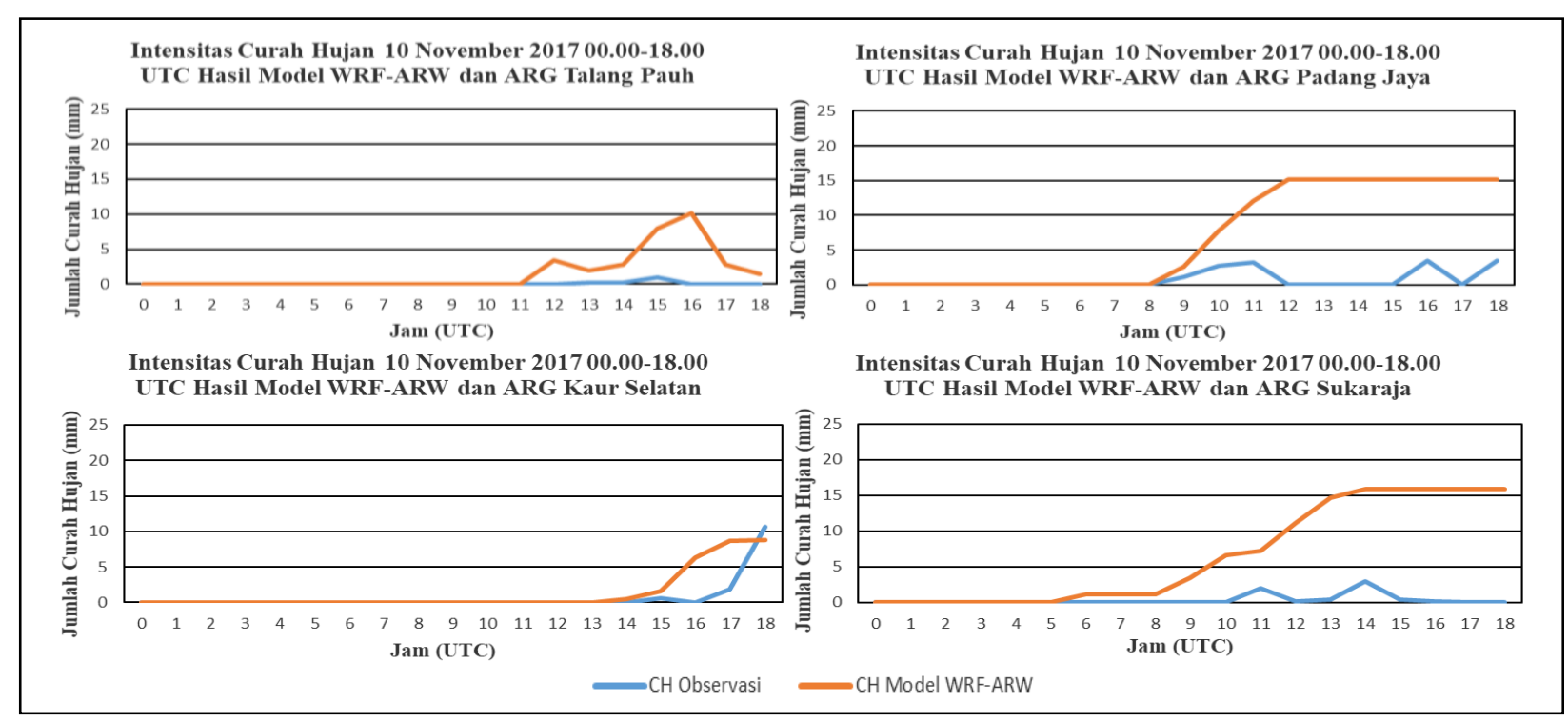

Gambar 7. Intensitas curah hujan ARG dengan hasil keluaran model WRF-ARW 


\section{pukul 00-18 UTC pada 10 November 2017 di Bengkulu}

Berdasarkan Tabel 2 nilai korelasi intensitas curah hujan hasil keluaran model WRFARW yang dibandingkan dengan ARG Padang Jaya sebesar 0.487 dengan nilai RMSE dan MAE sebesar 1.507 dan 0.793 yang menunjukkan tingkat kesalahan terkecil. Sedangkan hasil keluaran model WRF-ARW dengan ARG Talang Pauh memiliki nilai RMSE sebesar 3.102 dan nilai MAE sebesar 1.529 sehingga hasil keluaran model WRF-ARW semakin tidak akurat dibandingkan dengan data pengamatan. Sedangkan sebagian besar nilai korelasi yang dihasilkan dari model WRF-ARW menunjukkan korelasi positif lemah di mana data curah hujan observasi berbanding lurus dengan hasil keluaran model. Pada umumnya data curah hujan model WRF-ARW bernilai sangat tinggi dibandingkan data curah hujan observasi yang diambil dari beberapa titik Automatic Rain Gauge (ARG) yang diujikan.

Tabel 2. Nilai Korelasi, RMSE dan MAE parameter Curah Hujan

\begin{tabular}{lcccc}
\hline \multicolumn{2}{c}{ Data Curah Hujan } & $\begin{array}{c}\text { Nilai } \\
\text { Korelasi }\end{array}$ & $\begin{array}{c}\text { Nilai } \\
\text { RMSE }\end{array}$ & Nilai MAE \\
\hline WRF-ARW & ARG Talang Pauh & 0.543 & 3.102 & 1.529 \\
WRF-ARW & ARG Padang Jaya & 0.487 & 1.507 & 0.793 \\
WRF-ARW & ARG Kaur Selatan & 0.000 & 2.647 & 0.886 \\
WRF-ARW & ARG Sukaraja Seluma & 0.103 & 1.532 & 0.899 \\
\hline
\end{tabular}

\subsubsection{Nilai Reflectivity Hasil Model WRF-ARW Dengan Pengamatan Radar Cuaca}

Gambar 8 menunjukan perbandingan nilai reflectivity maksimum yang teramati dari hasil model WRF-ARW dan pengamatan radar cuaca diwilayah Bengkulu pada pukul 00.00-18.00 UTC. Nilai reflectivity model WRF-ARW dan hasil pngamatan radar cuaca masing-masing menunjukan awal peningkatan di waktu yang relatif berdekatan yaitu sekitar 06.00-08.00 UTC. Selain itu puncak nilai reflectivity antara keduanya terjadi di waktu yang sama yaitu pada pukul 10.00 UTC dengan nilai $55.5 \mathrm{dBz}$. Hal tersebut menunjukan bahwa model WRFARW cukup baik dalam memperkirakan nilai dBz akan tetapi jika dibandingkan dengan pengamatan radar cuaca yang dilihat secara spasial (Gambar 1), sebaran nilai reflectivity maksimum model WRF-ARW hanya dalam luasan yang lebih kecil dan lokasi sebaran nilai reflectivity tidak tepat pada lokasi terdeteksi QLCS.

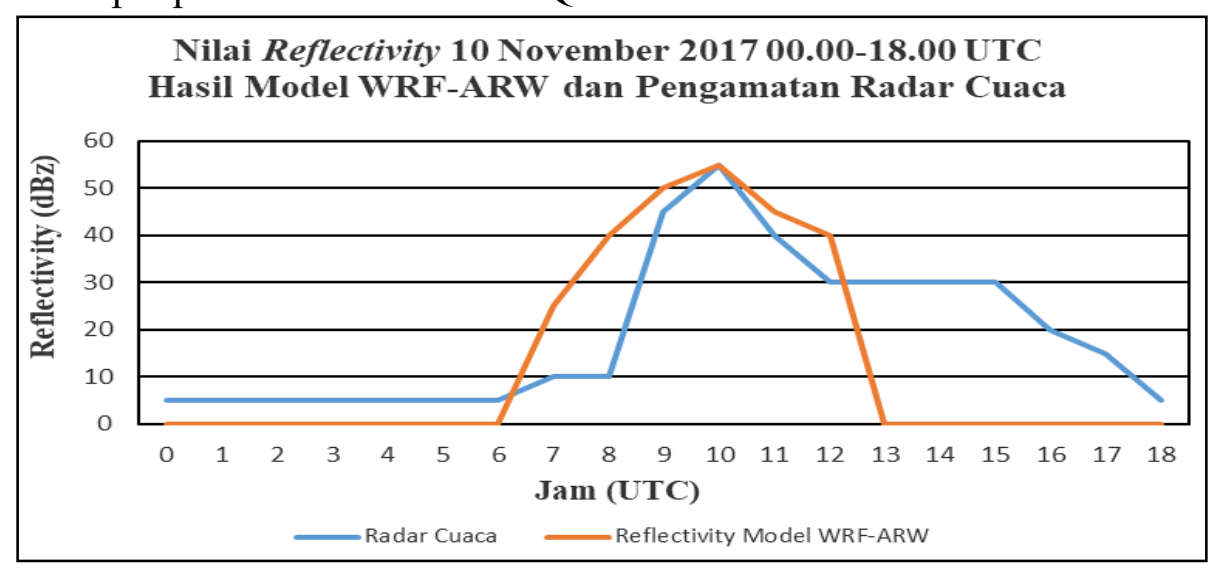

Gambar 8. Nilai Reflectivity maksimum hasil model WRF-ARW dan pada 00.00 - 18.00 UTC 10 November 2017 di Bengkulu 
Berdasarkan Tabel 3 nilai korelasi data reflectivity hasil keluaran model WRF-ARW yang dibandingkan dengan radar cuaca sebesar 0.684 dengan nilai RMSE sebesar 15.894 dan nilai MAE sebesar 12.105. Nilai tersebut menunjukan hasil keluaran model WRF-ARW masih kurang akurat dalam memodelkan data reflectivity.

Tabel 3. Nilai Korelasi, RMSE dan MAE parameter Curah Hujan

\begin{tabular}{cccc}
\hline Data Reflectivity & $\begin{array}{c}\text { Nilai } \\
\text { Korelasi }\end{array}$ & $\begin{array}{c}\text { Nilai } \\
\text { RMSE }\end{array}$ & $\begin{array}{c}\text { Nilai } \\
\text { MAE }\end{array}$ \\
\hline $\begin{array}{c}\text { WRF-ARW - Radar } \\
\text { Cuaca }\end{array}$ & 0.684 & 15.894 & 12.105 \\
\hline
\end{tabular}

\section{KESIMPULAN DAN SARAN}

Berdasarkan hasil penelitian dapat disimpulkan bahwa Quasi Linear Convective System (QLCS) terdeteksi dengan pengamatan radar cuaca Bengkulu mulai dari fase evolusi hingga disipasi. Fenomena ini pun mampu diidentifikasi dengan model WRF-ARW. Kondisi dinamika atmosfer berupa pola streamline, vertical velocity, kelembapan relatif, CAPE dan cloud fraction hasil keluaran model WRF-ARW cukup baik dalam merepresentasikan fenomena tersebut. Hasil verifikasi dengan data observasi menunjukan parameter curah hujan menghasilkan error yang lebih kecil dibandingkan dengan error hasil verifikasi nilai reflectivity. Hal tersebut menunjukan bahwa model WRF-ARW masih kurang akurat dalam memodelkan data reflectivity. Diharapkan penelitian selanjutnya dapat dilakukan dengan data banding yang lebih banyak dan menggunakan teknik permodelan WRF-ARW yang lebih baik.

\section{DAFTAR PUSTAKA}

Astuti, F. N., S, M. A. R., Kesaulya, E. C., \& N, I. R. (2019). Identifikasi Karakteristik Quasi Linear Convective System Di Kawasan Bengkulu Pada Oktober Sampai Desember 2017 Berbasis Citra Radar Cuaca. Prosiding Seminar Nasional Geotik 2019, 196-205.

Lombardo, K. A., \& Colle, B. A. (2010). The Spatial And Temporal Distribution Of Organized Convective Structures Over The Northeast And Their Ambient Conditions. Monthly Weather Review, 138(12), 4456-4474.

Orlanski, I. (1975). A Rational Subdivision Of Scales For Atmospheric Processes. Bulletin Of The American Meteorological Society, 56(5), 527-530.

Skamarock, W. C. (2008). A Description Of The Advances Research WRF Version 3. National Center For Atmospheric Research Boulder, Colorado, USA.

Tjasyono, B. Dan Harijono, S. W. B. (2013). Atmosfer Ekuatorial. Pusat Penelitian Dan Pengembangan, Badan Meteorologi Klimatologi Dan Geofisika, Jakarta.

Wardoyo, E. (2015). Radar Meteorologi, Jakarta: Badan Meteorologi Klimatologi dan Geofisika.

http://rda.ucar.edu diakses pada tanggal 1 Juli 2019 https://www.nssl.noaa.gov/education/svrwx101/thunderstorms/types/ diakses pada tanggal 9 Juli 2019 